\title{
Bacterial Conjunctivitis
}

National Cancer Institute

\section{Source}

National Cancer Institute. Bacterial Conjunctivitis. NCI Thesaurus. Code C53656.

Inflammation of the conjunctiva caused by a variety of bacterial agents. 